\title{
ISOLATION OF RECOMBINANT STRAINS WITH ENHANCED PECTINASE PRODUCTION BY PROTOPLAST FUSION BETWEEN PENICILLIUM EXPANSUM AND PENICILLIUM GRISEOROSEUM
}

\author{
Maurilio Antonio Varavallo ${ }^{1}$; Marisa Vieira de Queiroz ${ }^{2 *}$; Taís Guimarães Lana²; Admilson Toscano Ribeiro de Brito ${ }^{3}$; \\ Daniel Bonoto Gonçalves²; Elza Fernandes de Araújo ${ }^{2}$ \\ ${ }^{1}$ Faculdade de Biomedicina, Centro Universitário das Faculdades Metropolitanas Unidas, São Paulo-SP, Brazil; ${ }^{2}$ Departamento \\ de Microbiologia/BIOAGRO, Universidade Federal de Viçosa, Viçosa-MG, Brazil; ${ }^{3}$ CODAI, Universidade Federal Rural de \\ Pernambuco, Recife-PE
}

Submitted: February 07, 2006; Returned to authors for corrections: March 30, 2006; Approved: October 13, 2006

\begin{abstract}
Protoplast fusion between complementary auxotrophic and morphological mutant strains of Penicillium griseoroseum and $P$. expansum was induced by polyethylene glycol and calcium ions $\left(\mathrm{Ca}^{2+}\right)$. Fusant strains were obtained in minimal medium and a prototrophic strain, possibly diploid, was chosen for haplodization with the fungicide benomyl. Different recombinant strains were isolated and characterized for occurrence of auxotrophic mutations and pectinolytic enzyme production. The fusant prototrophic did not present higher pectinase production than the parental strains, but among 29 recombinants analyzed, four presented enhanced enzyme activities. The recombinant RGE27, which possesses the same auxotrophic and morphologic mutations as the $P$. griseoroseum parental strain, presented a considerable increase in polygalacturonase (3-fold) and pectin lyase production (1.2-fold).
\end{abstract}

Key words: Protoplast fusion, pectinases, Penicillium

\section{INTRODUCTION}

Since the parasexual cycle was first discovered by Pontecorvo and Roper (31), it has been described in important fungal species (6). From a biotechnological point of view, the parasexual cycle is of great importance for the improvement of fungi of industrial interest since most of these fungi do not have a sexual cycle. The parasexual cycle has successfully been applied in enzyme producing fungi, antibiotics and has been used for improvement of biocontrol efficiency in the genus Beauveria $(9,21,32,40,44)$.

The parasexual cycle initiates with heterokaryose, occurring through anastomosis of vegetative cells; followed by nuclear fusion, which gives rise to heterozygous diploids putatives and terminates with recombinant production by mitotic recombination and haplodization $(6,10,18,19,44)$. Spontaneous anastosis between different species can be hindered by the vegetative incompatibility among different strains. The incompatibility can be overcome by use of the protoplast fusion technique, which allows for production of haploid recombinants with the desired characteristics of the parental species. Interspecific protoplast fusion has already been described for several fungi, including Aspergillus nidulans with A. fumigatus (16), A. nidulans with A. rugulosus (22), A. oryzae with A. sojae (42), Aspergillus sp. with A. flavipes (38), Volvariella volvacea with $V$. bombycina (46) and Beauveria bassiana with $B$. sulfurescens $(13,44)$.

The spontaneous parasexual cycle in the Penicillium genus has been described for the species $P$. chrysogenum (30), $P$. expansum (8), P. italicum and P. digitatum (39), and P. roqueforti (15), while the induced parasexual cycle in $P$. griseoroseum was described by Santos (37). Fusions of interspecific protoplasts were obtained between $P$. chrysogenum and P. notatum (3) and between $P$. chrysogenum and $P$. roqueforti (4).

*Corresponding Author. Mailing address: Departamento de Microbiologia/BIOAGRO, Universidade Federal de Viçosa, Viçosa-MG. Cep: 36570-000, Brazil. Tel.: (31) 3899-2553 ou (31) 3899-2573. E-mail: mvqueiro@ufv.br 
Pectinolytic enzymes are of great commercial interest in the food industry for clarification of fruit juices and wines, for ripening cacao and coffee, for processing of conserved fruit $(12,25)$. These enzymes are also important in the textile industry, since pectic substances contained in the middle lamella and primary cell wall can be softened with enzymes in order to liberate the cellulose fibers from the plant cell wall $(7,41,45)$.

Several genetic studies have been carried out in our laboratories in order to sequence the structural and regulatory genes of the pectinolytic complex, and to isolate strains with enhanced pectinolytic enzyme activities. Different methodologies which have been used to achieve these goals include protoplast production and regeneration, mutant isolation and characterization, protoplast transformation, construction of a genomic library and isolation and characterization of genes coding polygalacturonases in $P$. griseoroseum and $P$. expansum $(14,17,33,34,35)$.

The fusion of interspecific protoplasts to genetically enhance pectinase production has only been described for the Aspergillus genus (38), in which fusion of A. flavipes with Aspergillus sp. protoplasts, resulted in diploids putatives with increased pectinase production.

The objective of this study was to carry out protoplast fusion between $P$. expansum and $P$. griseoroseum to obtain recombinant strains with increased pectinolytic enzyme activity.

\section{MATERIALAND METHODS}

\section{Microrganisms}

The wild type strains of Penicillium griseoroseum (PG) and $P$. expansum (PE) used in this study were isolated from forest seeds by Dr. James J. Muchovej, Departamento de Fitopatologia, Universidade Federal de Viçosa. The $P$. griseoroseum mutant PGLBF (leu, bio, fwn) is auxotrophic for leucine and biotin and produces brown conidia. This mutant was isolated using nitrosoguanidine (N-methyl-N'-nitro-N-nitrosoguanidine), as mutagenic agent (11). The mutant $P$. expansum PELW (lis, whi), obtained by irradiation of conidia with ultraviolet light, is a lysine auxotroph and produces white conidia (24). The reversion frequency was $<1 \times 10^{-6}$ in all mutants tested.

\section{Culture media}

The following media were used in this study: 1) Minimal Medium (MM) (31): $6.0 \mathrm{~g} / \mathrm{L} \mathrm{NaNO} 3,1.5 \mathrm{~g} / \mathrm{L} \mathrm{KH}_{2} \mathrm{PO}_{4}, 0.5 \mathrm{~g} / \mathrm{L} \mathrm{KCl}$, $0.5 \mathrm{~g} / \mathrm{L} \mathrm{MgSO}_{4} .7 \mathrm{H}_{2} \mathrm{O}, 0.01 \mathrm{~g} / \mathrm{L} \mathrm{FeSO}_{4}, 0.01 \mathrm{~g} / \mathrm{L} \mathrm{ZnSO}_{4}, 10.0 \mathrm{~g} / \mathrm{L}$ glucose, $15.0 \mathrm{~g} / \mathrm{L}$ agar (SIGMA); 2) Complete Medium (CM) (5, 31): minimal medium supplemented with $2.0 \mathrm{~g} / \mathrm{L}$ peptone, $1.5 \mathrm{~g} /$ L hydrolyzed casein, $2.0 \mathrm{~g} / \mathrm{L}$ yeast extract and $1.0 \mathrm{~mL}$ of a vitamin solution $(0.2 \mathrm{mg}$ biotin, $10.0 \mathrm{mg}$ p-aminobenzoic acid, $50.0 \mathrm{mg}$ pyridoxine, $50.0 \mathrm{mg}$ thiamin, $100.0 \mathrm{mg}$ nicotinic acid and 100.0 $\mathrm{mg}$ riboflavin in $100 \mathrm{~mL}$ distilled water); 3) enriched oatmeal agar (EOA): $40.0 \mathrm{~g} / \mathrm{L}$ oatmeal, $1.5 \mathrm{~g} / \mathrm{L}$ hydrolyzed casein, $2.0 \mathrm{~g} /$
L yeast extract, $2.0 \mathrm{~g} / \mathrm{L}$ peptone, $15.0 \mathrm{~g} / \mathrm{L}$ agar and $1.0 \mathrm{~mL}$ of the vitamin solution; 4) buffered mineral medium (BMM): $13.6 \mathrm{~g} / \mathrm{L}$ $\mathrm{K}_{2} \mathrm{HPO}_{4}, 7.6 \mathrm{~g} / \mathrm{L} \mathrm{KH}_{2} \mathrm{PO}_{4}, 2.0 \mathrm{~g} / \mathrm{L}\left(\mathrm{NH}_{4}\right)_{2} \mathrm{SO}_{4}, 3.0 \mathrm{~g} / \mathrm{L}$ citric pectin, $0.6 \mathrm{~g} / \mathrm{L}$ yeast extract and $1.1 \mathrm{~g} / \mathrm{L} \mathrm{MgSO}_{4} .7 \mathrm{H}_{2} \mathrm{O}$; and, 5) nonbuffered mineral medium (NBMM): $4.0 \mathrm{~g} / \mathrm{L} \mathrm{K} \mathrm{HPO}_{4}, 1.28 \mathrm{~g} / \mathrm{L}$ $\mathrm{KH}_{2} \mathrm{PO}_{4}, 2.0 \mathrm{~g} / \mathrm{L}\left(\mathrm{NH}_{4}\right)_{2} \mathrm{SO}_{4}, 3.0 \mathrm{~g} / \mathrm{L}$ citric pectin, $0.6 \mathrm{~g} / \mathrm{L}$ yeast extract and $1.1 \mathrm{~g} / \mathrm{L} \mathrm{MgSO}_{4} .7 \mathrm{H}_{2} \mathrm{O}$.

\section{Spontaneous heterokaryons formation}

P. griseoroseum PGLBF conidia and P. expansum PELW conidia were inoculated in sterile test tubes containing $3 \mathrm{~mL}$ of MM enriched with $2 \%(\mathrm{v} / \mathrm{v}) \mathrm{CM}$ and incubated at $25^{\circ} \mathrm{C}$ for 5 days.

\section{Protoplast isolation and fusion}

About $10^{6}$ conidia of the $P$. griseoroseum (PGLBF) and $P$. expansum (PELW) mutant strains were inoculated into $50 \mathrm{~mL}$ $\mathrm{CM}$ in $250 \mathrm{~mL}$ Erlenmeyer flasks and incubated for 18 hours at $150 \mathrm{rpm}$ and $25^{\circ} \mathrm{C}$. Cultures were filtered in gauze and the retained mycelia washed twice in distilled water. Approximately $300 \mathrm{mg}$ of fresh mycelia were incubated in $5.0 \mathrm{~mL}$ of osmotic stabilizer $(0.6 \mathrm{M} \mathrm{KCl}$ in $10 \mathrm{mM}$ sodium and potassium phosphate buffer, $\mathrm{pH} 5.8$ ) containing $5.0 \mathrm{mg} / \mathrm{mL}$ of Trichoderma harzianum lytic enzyme (SIGMA) for 3 hours at $80 \mathrm{rpm}$ and $30^{\circ} \mathrm{C}$ to produce protoplasts. The protoplasts were filtered through gauze, washed twice in osmotic stabilizer and centrifuged for 10 minutes at $3000 \mathrm{~g}$ and $4^{\circ} \mathrm{C}$. Protoplast fusion was carried out as follows: protoplast suspensions $\left(10^{6}\right.$ protoplasts $\left./ \mathrm{mL}\right)$ of each strain were centrifuged at $3000 \mathrm{~g}$ for 10 minutes at $4^{\circ} \mathrm{C}$, protoplasts were resuspended in $1.0 \mathrm{~mL}$ of a solution containing $30 \%(\mathrm{w} / \mathrm{v})$ polyethylene glycol (PEG 6000-SYNTH) and $0.05 \mathrm{mM} \mathrm{CaCl}_{2}$ in $0.05 \mathrm{mM}$ glycine- $\mathrm{NaOH}$ buffer, $\mathrm{pH}$ 8.0. After 10 minutes of incubation at $30^{\circ} \mathrm{C}$, the suspension was washed twice with 10 $\mathrm{mL}$ of osmotic stabilizer and centrifuged at $3000 \mathrm{~g}$ for 10 minutes at $4^{\circ} \mathrm{C}$. The sedimented protoplasts were resuspended in the same buffer and serial dilutions were prepared and plated for regeneration in $\mathrm{MM}$ and $\mathrm{CM}$ containing $1.0 \mathrm{M}$ sucrose as osmotic stabilizer, for the calculation of fusion frequency and incubated at $25^{\circ} \mathrm{C}$ for 5 days. Diploids putatives were identified by growth in $\mathrm{MM}$ and by the green conidial color.

\section{Haplodization}

To induce haplodization, diploids putatives were transferred by punctual inoculation to Petri dishes containing $\mathrm{CM}$ supplemented with $1.0 \mu \mathrm{g} / \mathrm{mL}$ of benomyl (methyl-1 (butylcarbamoyl)-2-benzimidazole carbamate) and incubated at $25^{\circ} \mathrm{C}$ for 10 days. The sectors presenting color similar to the parental strains were purified in $\mathrm{CM}$ and analyzed for genetic markers and pectinase activity.

\section{Conditions for enzyme production}

The fungi were grown for 9 days on plates containing EOA and $5.10^{7}$ conidia were harvested and inoculated in $125 \mathrm{~mL}$ 
Erlenmeyer flasks containing $50 \mathrm{~mL}$ culture medium (pH 6.3) and incubated under agitation of $150 \mathrm{rpm}$ at $25^{\circ} \mathrm{C}$. Polygalacturonase activity was determined after 96 hours of growth in NBMM, while pectin lyase activity was determined after 72 hours growth in BMM. After the growth period, mycelia were separated by filtration through sieves with pore diameters of $37 \mu \mathrm{m}$ and dried at $105^{\circ} \mathrm{C}$ to constant weight for biomass determination. Enzyme activity was measured in the culture filtrate. The experiment was installed in a completely randomized design with three replicates. Enzyme activity data were submitted to variance analysis and means were grouped by the Scott-Knott test at $1 \%$ probability. The experiment was repeated three times.

\section{Enzyme assay}

Pectin lyase activity was determined as described by Albersheim \& Killias (1). The reaction mixture, containing $1.0 \mathrm{~mL}$ of a $2.5 \%(\mathrm{w} / \mathrm{v})$ pectin solution in $0.1 \mathrm{M}$ phosphate and potassium buffer, $\mathrm{pH} 6.8$ and $1.5 \mathrm{~mL}$ of the culture filtrate, was incubated at $40^{\circ} \mathrm{C}$ for 30 minutes. The reaction was interrupted by transferring $0.5 \mathrm{~mL}$ of the reaction mixture to a tube containing $4.5 \mathrm{~mL}$ of 0.01 $\mathrm{N} \mathrm{HCl}$. The product formed was detected in a Micronal B-390 spectrophotometer by monitoring the absorption increase at $235 \mathrm{~nm}$. Control tubes were prepared at zero reaction time. One unit of pectin lyase activity (U) was defined as $\eta$ moles of unsaturated product formed per $\mathrm{mL}$ of culture mixture per minute per gram of dry mycelium $\left(\mathrm{U}_{\text {pectina lyase }}=\eta\right.$ moles of unsaturated product. $\mathrm{mL}^{-1} \cdot \mathrm{min}^{-1} \cdot \mathrm{g}$ dry mycelium $\left.{ }^{-1}\right)$. The molar extinction coefficient of the unsaturated product $\left(5.500 \mathrm{mM} . \mathrm{cm}^{-1}\right)$ was used for this calculation (2). Polygalacturonase activity was determined in a reaction mixture containing $0.5 \mathrm{~mL}$ of the culture filtrate, $0.5 \mathrm{~mL}$ of $1.2 \%$ polygalacturonic acid in $100 \mathrm{mM}$ sodium acetate buffer, $\mathrm{pH} 4.8$ and $0.1 \mathrm{M} \mathrm{NaCl}$, which was incubated at $40^{\circ} \mathrm{C}$ for 20 minutes. The formation of reducing sugar was measured by the 3.5 dinitrosalicylic acid method according to Miller (27) using galacturonic acid as standard. One unit of polygalacturonase activity (U) was defined as $\mu$ moles of galacturonic acid liberated per $\mathrm{mL}$ of culture filtrate per minute per gram of dry mycelium $\left(\mathrm{U}_{\text {poligalacturonase }}=\mu\right.$ moles of galacturonic acid $\mathrm{mL}^{-1} \cdot \mathrm{min}^{-1}$. g dry mycelium ${ }^{-1}$ ).

\section{RESULTS AND DISCUSSION}

\section{Heterokaryons and diploid formation}

No heterokaryon film formation could be observed when conidia of $P$. griseoroseum and $P$. expansum were mixed in minimal medium containing $2 \% \mathrm{CM}$, indicating incompatibility between these two species for the formation of heterokaryons by this technique. Heterokaryons were easily obtained when conidia of complementary mutants of each species were mixed $(11,24,37)$.

Anastomosis between hyphae does not always occur when the fungi belong to different species, possibly because of the presence of a determinant factor in the cell wall that blocks cell fusion thereby causing incompatibility (28). One way to overcome the incompatibility between strains is to apply the technique of protoplast fusion.

\section{Protoplast fusion}

Protoplast fusion of $P$. griseoroseum with $P$. expansum produced stable prototrophic fusant products with green conidia, possible diploids, even when grown in $\mathrm{CM}$, a result that differs from that obtained by Lana (24), who observed spontaneous haploidization in putative diploid strains of $P$. expansum. Prototrophic fusants of $P$. griseoroseum were extremely stable, even when grown in $\mathrm{CM}$ with addition of 0.75 $\mu \mathrm{g} / \mathrm{mL}$ of benomyl (37).

Conidia of a putative diploid strain (DGE) were transferred to plates containing CM supplemented with benomyl in order to obtain recombinant strains with enhanced pectinase production. Colony formation with white and fawn-colored sectors similar to the parental strains was observed. Twentynine recombinants were obtained and analyzed for auxotrophic and morphologic markers. These strains were designated RGEs (P. griseoroseum and P. expansum recombinants). Recombinant strains with different auxotrophic markers were isolated, and although none of them presented markers of both parents, prototrophic white strains were obtained (Table 1).

Table 1. Characterization of recombinant strains obtained by haploidization of the putative diploid strain (DGE), after protoplast fusion between $P$. expansum PELW and $P$. griseoroseum PGLB.

\begin{tabular}{cccc}
\hline Strain & Genotype & Strain & Genotype \\
\hline PELW & lys whi & RGE14 & leu fwn \\
PGLBF & leu bio fwn & RGE15 & leu fwn \\
DGE & prototrophic & RGE16 & prototrophic hi \\
RGE01 & leu fwn & RGE17 & prototrophic hhi \\
RGE02 & leu fwn & RGE18 & prototrophic whi \\
RGE03 & leu fwn & RGE19 & leu fwn \\
RGE04 & leu fwn & RGE20 & leu bio fwn \\
RGE05 & leu bio fwn & RGE21 & leu fwn \\
RGE06 & leu bio fwn & RGE22 & leu fwn \\
RGE07 & leu bio fwn & RGE23 & leu fwn \\
RGE08 & leu bio fwn & RGE24 & leu fwn \\
RGE09 & leu fwn & RGE25 & leu bio fwn \\
RGE10 & leu bio fwn & RGE26 & prototrophic whi \\
RGE11 & leu fwn & RGE27 & leu bio fwn \\
RGE12 & leu fwn & RGE28 & leu fwn \\
RGE13 & leu fwn & RGE29 & leu fwn \\
\hline
\end{tabular}

lys = lysine auxotroph; leu = leucine auxotroph; bio= biotin auxotroph; $w h i=$ white conidia; $f w n=$ fawn-colored conidia. 
When the spontaneous parasexual cycle of $P$. expansum was analyzed (24), it was noted that diploids putative were rather unstable and that recombinant sectors could easily be isolated.
Nevertheless, Santos (37) observed quite different results with P. griseoroseum, in which the parasexual cycle was not obtained spontaneously, and the prototrophic products of fusion were

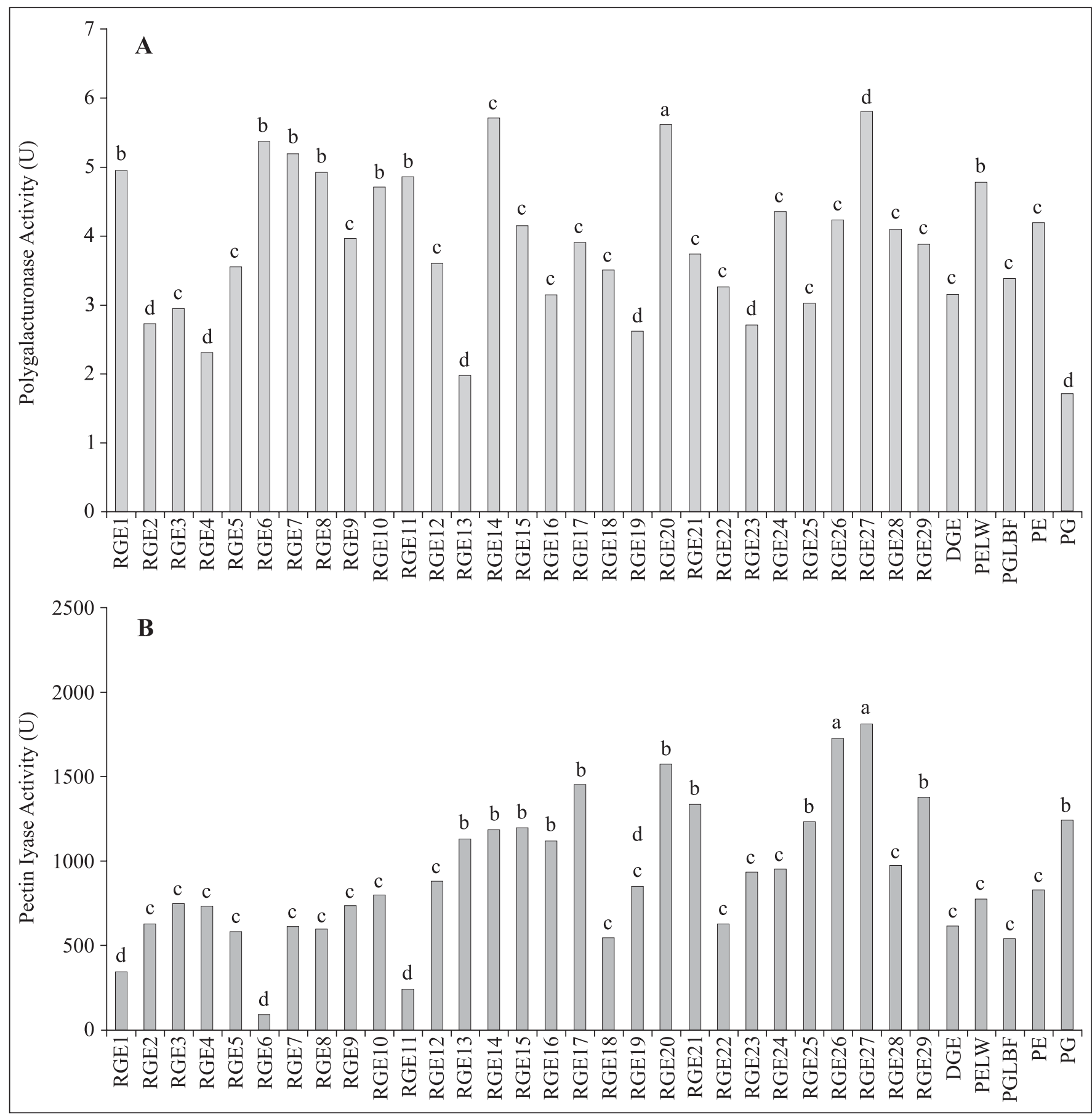

Figure 1. Polygalacturonase (A) and pectin lyase (B) activities of wild type strains of P. expansum (PE) and P. griseoroseum (PG), of the mutant parental strains (PELW and PGLBF), of the diploid obtained by protoplast fusion (DGE) and of the haploid recombinants (RGE1 to RGE29) grown in minimal medium at pH 6.3 with pectin as sole carbon source. Segments followed by the same letter are not significantly different by the Scott-Knott test at a level of $1 \%$. 
stable and produced few discrete sectors even when placed in $\mathrm{CM}$ supplemented with benomyl. The diploid putative resulting from the fusion between $P$. expansum and $P$. griseoroseum protoplasts presented behavior similar to that observed in $P$. expansum, with regard to haploidization, presenting readily observable sectors.

\section{Enzymatic activity}

Polygalacturonase and pectin lyase activities of the wild type (P. expansum and P. griseoroseum), parental (PGLBF e PELW), putative diploid strain (DGE) and recombinant strains (RGEs) were measured. The DGE strain did not present higher polygalacturonase or pectin lyase activity than the parental strains (Figure 1A e B). This result is similar to that found for diploids of A. niger var. awamori, which did not present a higher quantity of chymosin than the parental strains (9). Hoh et al. (20) obtained five diploids from A. niger, among which only one presented a higher $\beta$-glucosidase activity than the parental strains. However, Kirimura et al. (23) obtained one A. niger diploid strain that produced 1.2 times more citric acid than the parental strain in solid culture. Martinková et al. (26) also obtained A. niger diploids with a $15 \%$ higher citric acid production than the parental strains.

Several recombinants presented higher polygalacturonase activities than the wild type strains. Recombinants RGE 14, 20 and 27 had higher activities than the parental mutants (Figure 1A). In relation to pectin lyase production, most recombinants presented activity similar to that of the parental mutants, and inferior to the activity of the wild type strains. However, two recombinants, RGE26 and RGE27, presented increased PL activity, corresponding to $163.82 \%$ and $146.52 \%$, respectively, of the activity found in the P. griseoroseum wild type strain (Figure 1B). The recombinant RGE27 presented polygalacturonase activity of $121.58 \%$ in relation to PELW and of $340.58 \%$ in relation to the PG. Recombinant RGE26 did not present higher polygalacturonase activity than the parental mutants, and likewise for its pectin lyase activity. Among 29 recombinants obtained, RGE27, which presented the same auxotrophic and morphologic mutations as the P. griseoroseum parental mutant, was the most outstanding since it presented a considerable increase in both polygalacturonase and pectin lyase activities.

Hoh et al. (20) obtained A. niger recombinants by protoplast fusion which presented glycoamylase activity 2.5 times higher than in the parental strain. A similar result was obtained by Rubinder et al. (36) who was able to obtain a Thermomyces lanuginosus recombinant, which presented five-fold higher $\alpha$-amylase and aglycoamylase activities than the wild type strain. A. niger var. awamori recombinants were obtained which presented $15 \%$ greater chymosin production than the parental strains (9). Tahoun (40) obtained P. chrysogenum segregants with 290 to $390 \%$ greater penicillin production than the parental strains.

Our results confirm that protoplast fusion is a promising technique for obtaining strains with increased enzyme production. Regulatory mechanisms, organization and localization of the genes responsible for the enzymes of the pectinolytic complex of the Penicillium genus are not yet thoroughly understood but, based on the results presented in this paper, we can affirm that these genes were recombined during the parasexual cycle initiated by protoplast fusion. The recombinant RGE27, with enhanced polygalacturonase and pectin lyase activities, demonstrates that our principal objective, obtaining a recombinant with the desired characteristics, was achieved. The production of pectinases by RGE27 strain will be studied in a submerged fermentation system where different carbon sources will be tested with the objective of reducing production costs.

\section{ACKNOWLEDGMENTS}

The authors gratefully acknowledge the financial support of the Brazilian Agencies CNPq, FINEP, FAPEMIG and CAPES.

\section{RESUMO}

\section{Isolamento de linhagens recombinantes com maior produção de pectinases por meio de fusão de protoplastos entre Penicillium expansum e Penicillium griseoroseum}

Fusões de protoplastos entre linhagens mutantes auxotróficas e morfológicas complementares de Penicillium griseoroseum e P. expansum foram induzidas por polietilenoglicol e íons cálcio $\left(\mathrm{Ca}^{2+}\right)$. Fusionantes foram obtidos em meio mínimo e uma linhagem prototrófica, possivelmente diplóide, foi selecionada para a haploidização com o fungicida benomil. Diferentes linhagens recombinantes foram isoladas e caracterizadas quanto à presença de mutações auxotróficas e a produção de enzimas pectinolíticas. O fusionante prototrófico não apresentou maior atividade de pectinases em relação às linhagens parentais, entretanto, entre 29 recombinantes analisados, quatro apresentaram maiores atividades enzimáticas. $\mathrm{O}$ recombinante RGE27, o qual possui as mesmas mutações auxotróficas e morfológicas que a linhagem parental de P. griseoroseum, apresentou um aumento considerável na produção de poligalacturonase ( 3 vezes) e de pectina liase ( 1,2 vezes).

Palavras-chave: Fusão de protoplastos, pectinases, Penicillium

\section{REFERENCES}

1. Albersheim, P.; Killias, U. (1962) Studies relating to the purification and properties of pectin transeliminase. Arch. Biochem. Biophys, 97, 107-115.

2. Albersheim, P. (1966). Pectin lyase from fungi. In: Neufeld, E.F.; Ginsburg, V. (eds). Methods in Enzymology Vol. 8. Academic Press, New York, USA, p.628-631. 
3. Anné, J.; Peberdy, J.F. (1976). Induced fusion of fungal protoplasts following treatment with polyethylene glycol. J. Gen. Microbiol., 92, 413-417.

4. Anné, J.; Peberdy, J.F. (1985). Protoplast fusion and interspecies hybridization in Penicillium. In: Peberdy, J.F.; Ferenczy, L. (eds) Fungal Protoplasts. Marcel Dekker, New York, USA, p.259-277.

5. Azevedo, J.L.; Costa, S.O.P. (1973). Exercícios Práticos de Genética. EDUSP: Editora Nacional, São Paulo, SP.

6. Azevedo, J.L. (1998). Genética de Microrganismos. Editora da UFG, Goiânia, GO.

7. Baracat-Pereira, M.C.; Valentim, C.; Muchovej, J.J.; Silva, D.O. (1989). Selection of pectinolytic fungi for degumming of natural fibers. Biotechnol. Lett., 18, 899-902.

8. Barron, G.L. (1962). The parasexual cycle and linkage relationships in the storage rot fungus Penicillium expansum. Can. J. Bot., 40, 1603-1614.

9. Bodie, E.A.; Armstrong, G.L.; Dunn-Coleman, N.S. (1994). Strain improvement of chymosin-producing strains of Aspergillus niger var. awamori using parasexual recombination. Enz. Microbiol. Technol., 16, 376-382.

10. Bos, C.J. (1996). Fungal Genetics 1st edition. Marcel Dekker, New York, USA.

11. Brito, A.R.T. (1998). Isolamento e caracterização de mutantes de Penicillium griseoroseum. Viçosa, Brasil, 74p. (M.Sc. Dissertation. Departamento de Microbiologia. UFV).

12. Chesson, A. (1980). Maceration in relation to be post-harvest handling and processing of plant material. J. Appl. Bacteriol., 48, 145.

13. Couteaudier, Y.; Viaud, M.; Riba, G. (1996). Genetic nature, stability, and improved virulence of hybrids from protoplasts fusion in Beauveria. Microbial Ecol., 32, 1-10.

14. Dias, E.S.; Araújo, E.F.; Guimarães, W.V.; Coelho, J.L.C.; Silva, D.O. (1997). Production and regeneration of Penicillium expansum and Penicillium griseoroseum protoplasts. Braz. J. Microbiol., 28, 116-120.

15. Durand, N.; Reymond, P.; Fevre, M. (1992). Transmission and modification of transformation markers during an induced parassexual cycle in Penicillium roquefortii. Curr. Genet., 21, 377-383.

16. Ferenczy, L.; Szegedi, M.; Kevei, F. (1976). Interspecific protoplasts fusion and complementation in Aspergilli. Experientia 33, 184-186.

17. Fernandes-Salomão, T.M.; Amorim, A.C.R.; Chaves-Alves, V.M. Coelho, J.L.C.; Silva, D.O.; Araújo, E.F. (1996). Isolation of pectinases hyperproducing mutants of Penicillium expansum. Braz. J. Microbiol., 27, 15-18.

18. Fincham, J.R.S.; Day, P.R. (1971). Fungal Genetics 3rd edition. Blackwell Scientific Publications, Oxford.

19. Field, A.; Laane, M.M. (1970). The nuclear division and parassexual cycle in Penicillium. Genetica, 41, 517-524.

20. Hoh, Y.K.; Tan, T.K.; Yeoh, H. (1992). Protoplast fusion of $\beta$ glucosidase-producing Aspergillus niger strains. Appl. Biochem. Biotechnol., 37, 81-88.

21. Khattab, A.A.; Bazaraa, W.A. (2005). Screening, mutagenesis and protoplast fusion of Aspergillus niger for the enhancement of extracellular glucose oxidase production. J. Ind. Microbiol. Biotechnol., 32: 289-294.

22. Kevei, F.; Peberdy, J.F. (1977). Interspecific hybridization between Aspergillus nidulans and Aspergillus rugulosus by fusion of somatic protoplasts. J. Gen. Microbiol., 102, 255-262.

23. Kirimura, K.; Nakajima, I.; Lee, S.P.; Kawabe, S.; Usami, S. (1988). Citric acid production by the diploid strains of Aspergillus niger obtained by protoplast fusion. Appl. Microbiol. Biotechnol., 27, 504-506.

24. Lana, T.G. (1999). Isolamento e caracterização de linhagens diplóides e recombinantes em Penicillium expansum. Viçosa, Brasil, 55p. (M.Sc. Dissertation. Departamento de Microbiologia. UFV).

25. Manachini, P.L.; Parini, C.; Fortuna, M.G. (1988). Pectic enzymes of Aureobasidium pullulans LV 10. Enzyme Microbial Technol., 10, 682-685.
26. Martinková, L.; Musilková, E.; Ujcová, E.; Machek, F.; Seichert, L. (1990). Protoplast fusion in Aspergillus niger strains accumulating citric acid. Folia Microbiol., 35, 143-148.

27. Miller, G.L. (1959). Use of dinitrosalicylic acid reagent for determination of reducing sugar. Anal. Chem., 31, 426-428.

28. Peberdy, J.F. (1991). Fungal protoplasts. In: Bennett, J.W.; Lasure, L.L. (eds). More Gene Manipulation in Fungi. Academic Press, New York, USA, p.307-316

29. Pontecorvo, G.; Sermonti, G. (1953). Recombination without sexual reproduction in Penicillium chrysogenum. Nature, 172, 126-127.

30. Pontecorvo, G.; Sermonti, G. (1954). Parasexual recombination in Penicillium chrysogenum. J. Gen. Microbiol., 11, 94-104.

31. Pontecorvo, G.; Roper, J.A.; Hemmons, L.M.; MacDonald, K.D.; Bufton, A.W.J. (1953). The genetics of Aspergillus nidulans. Adv. Genet., 5, 141-238.

32. Prabavathy, V.R.; Mathivanan, N.; Sagadevan, E.; Murugesan, K.; Lalithakumari, D. (2006). Intra-strain protoplast fusion enhances carboxymethyl cellulose activity in Trichoderma reesi. Enzyme Microbial Technol., 38, 719-723.

33. Queiroz, M.V.; Barros, A.O.; Barros, E.G.; Guimarães, W.V.; Araújo, E.F. (1998). Transformation of Penicillium griseoroseum nitrate reductase mutant with the nia gene from Fusarium oxysporum. Can. J. Microbiol., 44, 487-489.

34. Ribon, A.O.B.; Coelho J.L.C.; Barros, E.G.; Araújo, E.F. (1999). Cloning and characterization of the gene encoding the endopolygalacturonase of Penicillium griseoroseum. Biotechnol. Lett., 21, 395-399.

35. Ribon, A.O.B.; Queiroz, M.V.; Araújo, E.F. (2002). Structural organization of polygalacturonase-encoding genes from Penicillium griseoroseum. Genet. Mol. Biol., 25, 489-493.

36. Rubinder, K.; Chadha, B.S.; Singh, S.; Saini, H.S. (2000). Amylase hyper-producing haploid recombinant strains of Thermomyces lanuginosus obtained by intraspecific protoplast fusion. Can. J. Microbiol., 46, 669-673.

37. Santos, J.K. (1999). Fusão de protoplastos em Penicillium griseoroseum visando o melhoramento na produção de pectinases. Viçosa, Brasil, 65p. (Monografia de graduação, Departamento de Microbiologia, UFV).

38. Solís, S.; Flores, M.E.; Huitrón, C. (1997). Improvement of pectinase production by interspecific hybrids of Aspergillus strains. Lett. Appl. Microbiol., 24, 77-81.

39. Strømnaes, O.; Garber, E.D.; Beraha, L. (1964). Genetics of phytopathogenic fungi IX. Heterocaryosis and the parasexual cycle in Penicillium italicum and Penicillium digitatum. Can. J. Bot., 42 , 423-427.

40. Tahoun, M.K. (1993). Gene manipulation by protoplast fusion and penicillin production by Penicillium chrysogenum. Appl. Biochem. Biotechnol., 39, 445-453.

41. Tanabe, H.; Kobayashi, Y. (1986). Enzymatic maceration mechanism in biochemical pulping of mitsumata (Edgeworthia papyrifera Sieb. Et Zucc) bast. Agric. Biol. Chem., 50, 2779-2784

42. Ushjima, S.; Nakadai, T.; Uchida, K. (1991). Interspecific electrofusion of protoplasts between Aspergillus oryzae and Aspergillus sojae. Agri. Biol. Chem., 55, 129-136.

43. Vazquez, F.; Heluane, H.; Spencer, J.F.T.; Spencer, D.M.; Figueroa, L.I.C. (1997). Fusion between protoplasts of Pichia stipitis and isolated filamentous fungi nuclei. Enzyme Microbial. Technol., 21, 32-38.

44. Viaud, M.; Couteaudier, Y.; Riba, G. (1998). Molecular analysis of hypervirulent somatic hybrids of the entomopathogenic fungi Beauveria bassiana and Beauveria sulfurescens. Appl. Envirol. Microbiol., 64, 88-93.

45. Whitaker, J.R. (1984). Pectis substances, pectic enzymes and haze formation in fruit juices. Enzyme Microbial. Technol., 6, 341-349.

46. Zhao, J.; Chang, S.T. (1997). Interspecific hybridization between Volvariella volvacea and $V$. bombycina by PEG-induced protoplast fusion. W. J. Microbiol. \& Biotechnol., 13, 145-151. 